\title{
KINETIKA FERMENTASI YOGHURT YANG DIPERKAYA UBI JALAR (Ipomea batatas)
}

\section{KINETICS FERMENTATION of YOGHURT ENRICHED BY SWEET POTATO (Ipomea batatas)}

\author{
Rohula Utami, MAM Andriani, Zoraya A Putri \\ Ilmu dan Teknologi Pangan Fakultas Pertanian Universitas Sebelas Maret
}

\begin{abstract}
ABSTRAK
Tujuan dari penelitian ini adalah untuk mengetahui pengaruh dari kinetika fermentasi dari yoghurt yang diperkaya oleh ubi jalar ( Ipomea batatas $L$. ). Parameter dari kinetika fermentasi terdiri dari laju pertumbuhan spesifik $(\mu)$, waktu pengganda $\left(t_{d}\right)$, derajat darab $(n)$, perkembangan menghasilkan telah tetap ( $\mathrm{Yx} / \mathrm{s})$, produk menghasilkan telah tetap ( $\mathrm{Yp} / \mathrm{s})$, dan efisiensi penghasilan dari asam susu. Hasil penelitian menunjukkan, angka dari laju pertumbuhan spesifik ( . ), di yoghurt dataran adalah 0.4809 / jam, yoghurt putih adalah 0.4510 / jam, yoghurt warna ungu 0.5589 / yoghurt jam dan buah jeruk adalah 0.5880 / jam. Angka dari waktu pengganda (td) di yoghurt adalah 1.4513 jam, memutihi yoghurt adalah 1.8393 jam, yoghurt warna ungu adalah 1.3806 jam, dan yoghurt jeruk adalah 1.2074 jam. Angka dari derajat bebas (n ) di yoghurt adalah 4.9567 times, yoghurt putih adalah 5.5671 waktu, yoghurt warna ungu adalah 5.6837 waktu, dan yoghurt jeruk adalah 6.0985 waktu. Angka dari Telah Tetap Hasil Investasi Perkembangan (Yx / s) dan Telah Tetap Hasil Investasi Produk Yp / s berturut-turut di yoghurt adalah 4,5 $\mathrm{x} 10^{5} \mathrm{cfu} / \mathrm{mg}$ dan $0.082 \mathrm{mg}$, yoghurt putih adalah $4,2 \times 10^{5} \mathrm{cfu} / \mathrm{mg}$ dan $0.139 \mathrm{mg}$, yoghurt warna ungu adalah $7,5 \times 10^{5} \mathrm{cfu} / \mathrm{mg}$ dan memasuki,0712 mg, yoghurt jeruk adalah $6,8 \times 10^{5} \mathrm{cfu} / \mathrm{mg}$ dan $0.1046 \mathrm{mg}$. Angka dari efisiensi penghasilan dari asam susu selama fermentasi di yoghurt adalah 7,633 \%, yoghurt putih adalah 6,458\%, yoghurt warna ungu adalah 4,739\% dan yoghurt jeruk adalah $6,479 \%$.
\end{abstract}

\section{ABSTRACT}

The purpose of this research is to know the behavior of kinetics fermentation of yoghurt enriched by sweet potato (Ipomea batatas L.). The parameter of kinetics fermentation consist of spesific growth rate $(\mu)$, doubling time $\left(t_{d}\right)$, multiplication degree $(n)$, growth yield constant $(Y x / s)$, product yield constant $(\mathrm{Yp} / \mathrm{s})$, and production efficiency of lactic acid.

The result indicate that, the number of spesific growth rate $(\mu)$, in plain yoghurt is 0.4809 /hour, white yoghurt is $0.4510 /$ hour, purple yoghurt 0.5589 /hour and orange yoghurt is $0.5880 /$ hour. The number of doubling time (td) in plain yoghurt is 1.4513 hours, white yoghurt is 1.8393 hours, purple yoghurt is 1.3806 hours, and orange yoghurt is 1.2074 hours. The number of multiplication degree (n) in plain yoghurt is 4.9567 times, white yoghurt is 5.5671 times, purple yoghurt is 5.6837 times, and orange yoghurt is 6.0985 times. The number of Growth Yield Constant (Yx/s) and Product Yield Constant Yp/s successively in plain yoghurt is $4,5 \times 10^{5} \mathrm{cfu} / \mathrm{mg}$ and $0.082 \mathrm{mg}$, white yoghurt is $4,2 \times 10^{5} \mathrm{cfu} / \mathrm{mg}$ and 0.139 $\mathrm{mg}$, purple yoghurt is $7,5 \times 10^{5} \mathrm{cfu} / \mathrm{mg}$ and $0,0712 \mathrm{mg}$, orange yoghurt is $6,8 \times 10^{5} \mathrm{cfu} / \mathrm{mg}$ and $0.1046 \mathrm{mg}$. The number of production efficiency of lactic acid during the fermentation in plain yoghurt is 7,633\%, white yoghurt is 6,458\%, purple yoghurt is $4,739 \%$ and orange yoghurt is $6,479 \%$.

Keywords : yoghurt, sweet potato, kinetics fermentations.

\section{PENDAHULUAN}

Konsumsi produk pangan hasil fermentasi semakin meningkat hal ini disebabkan karena kesadaran konsumen untuk mengkonsumsi makanan yang sehat juga semakin meningkat. Produk-produk fermentasi bisa berasal dari berbagai bahan dasar, baik yang berbahan dari produk hewani maupun non hewani, salah satunya yang paling banyak dimanfaatkan adalah produk fermentasi berbasis susu. Salah satu produk fermentasi berbasis susu adalah yoghurt. Yoghurt adalah produk susu fermentasi berbentuk semi solid yang dihasilkan melalui proses fermentasi susu dengan menggunkan bakteri asam laktat. Melalui perubahan kimiawi 
yang terjadi selam proses fermentasi dihasilkan suatu produk yang mempunyai tekstur, flavor, dan rasa yang khas. Selain itu juga mempunyai nilai nutrisi yang lebih baik dibandingkan susu segar. Salah satu faktor yang mempengaruhi kualitas yoghurt adalah subtrat yang digunakan sebagai media fermentasi. Salah satu bahan yang dapat digunakan sebagai bahan tambahan subtrat pembuatan yoghurt adalah ubi jalar.

Ubi jalar yang secara umum dikenal berupa ubi jalar putih, ubi jalar orange dan ubi jalar ungu. Jenis umbi keluarga Convolvuceae ini memang sudah dikenal sebagai sumber karbohidrat yang mengandung betakaroten, anthosianin, vitamin E, kalsium dan zat besi juga serat. Aktivitas antioksidan ubi jalar orange antara 2.26 - 10.95\% sedangkan ubi jalar ungu antara 61,24 - 89,06\% (Widjanarko, 2008). Choong et.all (2007) juga melaporkan bahwa dari beberapa varietas ubi jalar berdasarkan warna umbinya, aktivitas antioksidan tertinggi ditunjukkan oleh ubi jalar ungu, sedangkan yang terendah pada ubi jalar putih. Akan tetapi Del Pozo et.all (2002) melaporkan adanya aktivitas antimikroba oleh antosianin wortel hitam dan anggur merah. Sehingga penambahan ekstrak ubi jalar pada yoghurt diduga mempengaruhi pertumbuhan mikroba kultur yoghurt.

Selain mengandung antioksidan, ubi jalar juga mengandung oligosakarida. Menurut Apraidji (2006), oligosakarida dalam ubi jalar merupakan komponen nongizi yang tidak tercerna tetapi bermanfaat bagi pertumbuhan bakteri probiotik sehingga ubi jalar dapat berfungsi sebagai prebiotik.Oleh karena itu penambahan ubi jalar dalam yoghurt juga mempengaruhi kehidupan mikroba kultur yoghurt yang digunakan dan proses fermentasi yoghurt. Proses fermentasi dapat tergambarkan dari kinetika fermentasi.

Studi kinetika pertumbuhan dan fermentasi diperlukan sebagai dasar untuk memahami setiap proses fermentasi. Kinetika fermentasi menggambarkan pertumbuhan dan pembentukan produk oleh mikroorganisme. Kinetika pertumbuhan dan pembentukan produk mempengaruhi kemampuan respons sel dan disinilah letak perlunya studi kinetika pertumbuhan dalam proses fermentasi secara rasional (Judoamidjojo, dkk, 1992). Oleh karena itu perlu dilakukan penelitian yang mengkaji bagaimana kinetika fermentasi yoghurt yang diperkaya dengan ubi jalar.

Tujuan dari penelitian ini adalah untuk mengetahui perilaku kinetika fermentasi yang terjadi selama proses fermentasi yoghurt dengan penambahan ekstrak ubi jalar putih, orange, dan ungu yang meliputi:Kecepatan pertumbuhan spesifik $(\mu)$, waktu penggandaan sel ( td ), derajat multiplikasi (n), hasil pertumbuhan (growth yield constant) $\mathrm{y} \mathrm{x} / \mathrm{s}$ dan pembentukan produk (produk yield constant) y p/s, dan efisiensi pembentukan asam laktat selama fermentasi

\section{METODOLOGI PENELITIAN}

Bahan dasar yang digunakan dalam penelitian ini adalah susu sapi segar, susu skim, ubi jalar (putih,orange dan ungu) serta starter yaitu Streptococcus thermophilus FNCC 0040 dan Lactobacillus bulgaricus FNCC 0041. Selain itu juga digunakan bahan pembantu yang digunakan meliputi reagensia dan indikator untuk analisa kadar laktosa, analisa kadar asam laktat, dan media untuk pertumbuhan bakteri.

Penelitian dilakukan pada beberapa tahap yaitu :

a. Pembiakan bakteri

Biakan murni Streptococcus thermophilus FNCC 0040 dan Lactobacillus bulgaricus FNCC 0041 diperbanyak dengan memindahkan kultur bakteri tersebut ke dalam beberapa tabung reaksi yang berisi media cair MRS. Kegiatan ini dilakukan dengan cara mengambil 1 ose kultur bakteri secara aseptis kemudian dimasukkan dalam tabung reaksi.

b. Pembuatan starter induk

Susu skim disterilisasi pada suhu $121{ }^{\circ} \mathrm{C}$ selama 15 menit kemudian didinginkan sampai suhu $40{ }^{\circ} \mathrm{C}$. Setelah itu, diinokulasikan dengan kultur hasil pembiakan dalam media MRS dan diinkubasi pada suhu $40{ }^{\circ} \mathrm{C}$ selama 24 jam.

c. Pembuatan starter siap pakai

Susu skim disterilisasi pada suhu $121{ }^{\circ} \mathrm{C}$ selama 15 menit kemudian didinginkan sampai suhu $40{ }^{\circ} \mathrm{C}$ dan diinokulasikan dengan starter induk $2 \%$. Selanjutnya diinkubasi pada suhu $40{ }^{\circ} \mathrm{C}$ selama 24 jam.

d. Pembuatan ekstrak ubi jalar

Ditimbang $1 \mathrm{~kg}$ ubi jalar kemudian dikupas dan dicuci sampai bersih. Setelah itu, ubi jalar diiris kecil-kecil sebesar dadu lalu dimasukkan dalam juicer untuk menghasilkan bubur ubi jalar. Bubur ubi jalar dituang dalam beker glass $500 \mathrm{ml}$ menggunakan corong yang dilapisi kain saring dan didiamkan selama 30 menit kemudian filtratnya diambil. Fitrat ini merupakan ekstrak ubi jalar yang siap digunakan untuk membuat yoghurt.

e. Pembuatan Yoghurt

Susu segar, susu skim $(5 \%$ b/v), dan ekstrak ubi jalar $(10 \% \mathrm{v} / \mathrm{v})$ di masukkan ke dalam Erlenmeyer dan dipasteurisasi suhu $90{ }^{0} \mathrm{C}$ selama 15 menit, kemudian di dinginkan 
sampai suhunya $40-45 \quad{ }^{0} \mathrm{C}$. Selanjutnya, inokulasi starter menggunakan Streptococcus thermophilus FNCC 0040 dan Lactobacillus bulgaricus FNCC 0041 dengan perbandingan 1:1 sebanyak 2,5\% (v/v), kemudian digojok hingga homogen. Susu dan ekstrak ubi jalar yang telah diinokulasi dengan starter tadi lalu dimasukkan ke dalam botol pengemas kemudian diinkubasi selama 15 jam pada suhu $40{ }^{\circ} \mathrm{C}$ hingga dihasilkan yoghurt.

f. Analisa jumlah bakteri, kadar laktosa, dan analisa kadar asam laktat

Pada interval tertentu dilakukan analisis jumlah bakteri dengan Metode Standart Plate Count, analisa kadar laktosa menurut Sudarmadji, dkk (1984) dengan Metode Nelson Somoyogi, analisa kadar asam laktat dilakukan dengan Metode Titrimetri $\mathrm{NaOH}$ 0,1N menurut Soewedo (1994). Pengamatan dilakukan pada jam ke: $0,1,2,3,4,5,6,7,8$, 9, 10, 11, 12, 13, 14, dan 15. Hasil pengamatan dibuat grafik yang menunjukkan hubungan antara jumlah bakteri, kadar laktosa, dan kadar asam laktat dengan waktu fermentasi. Masing-masing perlakuan dilakukan 3 kali ulangan analisis.

\section{HASIL DAN PEMBAHASAN}

Pada penelitian ini dilakukan pengukuran perilaku kinetika fermentasi selama proses pembuatan yoghurt yang diperkaya dengan berbagai jenis ekstrak ubi jalar, yaitu ubi jalar putih, orange, dan ungu. Sedangkan sebagai perlakuan kontrol adalah yoghurt susu. Untuk mengetahui perilaku kinetika fermentasi dari masing-masing yoghurt selama pembuatan yoghurt maka dilakukan pengamatan terhadap jumlah sel, kadar laktosa, dan kadar asam laktat.

Pengujian jumlah sel pada yoghurt kontrol dan yoghurt yang diperkaya dengan ubi jalar menunjukkan bahwa jumlah sel selama fermentasi mengalami masa adaptasi pada jam ke-0 sampai jam ke-1. Fase logaritmik terjadi pada jam ke-1 sampai jam ke-7. Fase stationer terjadi pada jam ke-8 sampai jam ke-9. Fase kematian pada jam ke-10, yaitu ditandai dengan penurunan jumlah sel secara cepat.

Berdasarkan hasil penelitian juga diketahui bahwa selama fermentasi terjadi hubungan dimana kadar laktosa mengalami penurunan dan kadar asam laktat mengalami kenaikan. Kadar laktosa terus mengalami penurunan karena dimanfaatkan oleh sel untuk tumbuh dan untuk membentuk asam laktat. Hal inilah yang menyebabkan kenaikan kadar asam laktat. Semakin banyak kadar laktosa yang dimanfaatkan maka kadar asam laktat akan semakin meningkat. Meningkatnya kadar asam laktat juga berkaitan dengan penurunan $\mathrm{pH}$.

Dari hasil pengamatan tersebut kemudian akan dibahas lebih lanjut tentang kecepatan pertumbuhan spesifik, waktu penggandaan (td), derajat multiplikasi/banyak penggandaan (n), hasil pertumbuhan (Growth Yield Constant) $\mathrm{Y}_{\mathrm{x} / \mathrm{s}}$, pembentukan produk (Produk Yield Constant) Y $\mathrm{p} / \mathrm{s}$, efisiensi pembentukan asam laktat selama fermentasi. Tabel 1 menunjukkan perilaku kinetika fermentasi yogurt kontrol dan yoghurt yang diperkaya dengan ubi jalar.

\section{a. Kecepatan Pertumbuhan Spesifik selama Fermentasi}

Kecepatan pertumbuhan spesifik $(\mu)$ adalah kecepatan pertumbuhan per satuan jumlah biomassa dan mempunyai satuan yang berupa kebalikan dari satuan waktu $(1 / \mathrm{t})$. Penentuan kecepatan pertumbuhan spesifik ini berdasarkan pada pola pertumbuhan logaritmik karena semua pertumbuhan adalah eksponensial sehingga yang dipakai adalah fase logaritmik. Tabel 1 menunjukkan data pertumbuhan spesifik selama fermentasi yoghurt yang diperkaya dengan ubi jalar.

Kecepatan pertumbuhan spesifik fermentasi yoghurt orange paling cepat dibandingkan yang lainnya, yaitu $0,5880 /$ jam. Secara berurutan kecepatan spesifik dari yang paling tinggi ke yang paling kecil adalah yoghurt orange, yoghurt ungu, yoghurt kontrol, dan yoghurt putih. Sedangkan kecepatan pertumbuhan spesifik selama fermentasi yoghurt yang diperkaya dengan ubi jalar ungu adalah $0,5589 /$ jam. Kecepatan pertumbuhan spesifik selama fermentasi yoghurt kontrol adalah 0,4809/jam. Kecepatan pertumbuhan spesifik selama fermentasi yoghurt dengan penambahan ekstrak ubi jalar putih adalah 0,4510/jam.

Tabel 1. Kinetika Fermentasi Yoghurt Kontrol dan Yoghurt yang Diperkaya dengan Ubi Jalar.

\begin{tabular}{lcccccc}
\hline \multicolumn{1}{c}{ Jenis yoghurt } & $(\mu)$ & $\mathrm{td}$ & $\mathrm{n}$ & $\mathrm{Y} \mathrm{x} / \mathrm{s}$, & $\mathrm{Y} \mathrm{p} / \mathrm{s}$ & Efisiensi \\
\hline Yoghurt kontrol & 0,4809 & 1,4513 & 4,9567 & $4,5 \times 10^{5}$ & 0,0820 & 7,633 \\
Yoghurt Putih & 0,4510 & 1,8393 & 5,5671 & $4,2 \times 10^{5}$ & 0,139 & 6,458 \\
Yoghurt Ungu & 0,5589 & 1,3806 & 5,6837 & $7,5 \times 10^{5}$ & 0,0712 & 4,739 \\
Yoghurt Orange & 0,5880 & 1,2074 & 6,0985 & $6,8 \times 10^{5}$ & 0,1046 & 6,479 \\
\hline
\end{tabular}




\section{b. Waktu penggandaan ( td )}

Pertumbuhan mikrobia biasanya ditentukan oleh waktu yang diperlukan untuk menggandakan sel. Banyaknya waktu penggandaan disebut juga doubling time (Td). Penentuan waktu penggandaan sel ini didasarkan dari nilai kecepatan pertumbuhan spesifik dengan hubungan berbanding terbalik. Apabila kecepatan pertumbuhan spesifik mikrobia tinggi, maka waktu yang dibutuhkan mikrobia untuk menggandakan diri justru akan semakin kecil atau dengan kata lain semakin singkat.

Tabel 1 menunjukkan bahwa yoghurt kontrol membutuhkan waktu untuk mengganda selama 1,4513 jam atau 87,078 menit, yoghurt putih memerlukan waktu 1,8393 jam atau 110,358 menit, yoghurt ungu memerlukan waktu 1,3806 jam atau 82,836 menit, dan yoghurt orange membutuhkan waktu 1,2074 jam atau 72,444 menit. Penambahan ekstrak ubi jalar orange memiliki waktu penggandaan (td) yang paling singkat, diikuti oleh ekstrak ubi jalar ungu, kemudian yoghurt kontrol dan yang paling lama adalah dengan penambahan ekstrak ubi jalar putih.

\section{c. Derajat Multiplikasi/Banyak Penggandaan (n)}

Derajat multiplikasi adalah hasil bagi antara $\mathrm{x} / \mathrm{x} 0$ yang menunjukkan banyaknya penggandaan yang terjadi selama proses fermentasi berlangsung. Penentuan derajat multiplikasi ini juga didasarkan pada fase logaritmik seperi parameter-parameter sebelumnya. Tabel 1 menunjukkan derajat multiplikasi/banyak penggandaan selama fermentasi.

Pada pembuatan yoghurt kontrol penentuan derajat multiplikasi (n) merupakan hasil bagi antara jumlah sel yang tumbuh pada jam ke-7 dengan jumlah sel pada jam ke-0 karena akhir dari fase log adalah pada jam ke-7. Berdasarkan perhitungan tersebut dapat diperoleh banyaknya penggandaan pada yoghurt kontrol 4,9567 kali selama fermentasi. Pada pembuatan yoghurt dengan penambahan ekstrak ubi jalar putih diperoleh banyaknya penggandaan 5,5671 kali. Pada fermentasi yoghurt dengan penambahan ekstrak ubi jalar ungu banyaknya penggandaan 5,6837 kali. Dan untuk fermentasi yoghurt dengan penambahan ekstrak ubi jalar orange banyaknya penggandaan adalah 6,0985. Semakin banyak mengganda menunjukkan bahwa sel yang membelah menghasilkan sel baru semakin banyak.

Berdasarkan kecepatan pertumbuhan spesifik ( $\left.{ }^{\mu}\right)$, waktu penggandaan (td), serta derajat multiplikasi/banyak penggandaan (n) selama fermantasi yoghurt diketahui bahwa yoghurt orange memiliki hasil tertinggi dibandingkan perlakuan yang lainnya. Pada yoghurt orange memiliki kecepatatn pertumbuhan spesifik yang paling tinggi, waktu pembelahan yang paling singkat dan penggandaan sel yang paling banyak. Kecepatan petumbuhan yang paling tinggi akan menghasilkan waktu penggandaan yang singkat, sehingga ini menyebabkan jumlah sel yang membelah juga semakin banyak dalam waktu yang cepat, meskipun dalam fermentasi yoghurt ini bukan jumlah sel yang menjadi tujuan utama tetapi dari penggandaan sel inilah yang nantinya diharapkan mempunyai aktivitas tinggi untuk menghasilkan produk.

\section{d. Hasil Pertumbuhan (Growth Yield Constant) $\mathrm{Y}_{\mathrm{X} / \mathrm{S}}$}

Pertumbuhan dan pembentukan produk oleh mikroorganisme adalah proses biokonversi yaitu nutrien kimia yang diberikan kepada proses fermentasi dikonversi menjadi massa sel dan metabolitnya. Growth yield adalah hasil bagi antara perubahan jumlah biomassa dengan substrat. Growth yield merupakan suatu cara yang penting untuk menyatakan kebutuhan nutrisi oleh suatu mikroorganisme secara kuantitatif. Tabel 1 memperlihatkan besarnya hasil pertumbuhan (Growth Yield Constant) Y $\mathrm{x} / \mathrm{s}$ pada pembuatan yoghurt kontrol sebesar $4,5 \times 10^{5} \mathrm{cfu} / \mathrm{mg}$, yoghurt putih sebesar $4,2 \times 10^{5} \mathrm{cfu} / \mathrm{mg}$, yoghurt ungu sebesar $7,5 \times 10^{5}$ $\mathrm{cfu} / \mathrm{mg}$, dan yoghurt orange sebesar $6,8 \times 10^{5}$ $\mathrm{cfu} / \mathrm{mg}$.

\section{e. Pembentukan Produk (Produk Yield Constant) Y p/s}

Produk Yield Constant menunjukkan banyaknya nutrisi yang digunakan oleh mikoorganisme untuk membentuk produk. Pada pembuatan yoghurt substrat digunakan untuk pembentukan produk (asam laktat). Pembentukan Produk (Produk Yield Constant) Y p/s didefinisikan sebagai perbandingan antara besarnya produk yang terbentuk dengan substrat yang dirombak. Tabel 1 menunjukkan besarnya hasil Pembentukan Produk (Produk Yield Constant) $\mathrm{Y} \mathrm{p} / \mathrm{s}$ selama fermentasi. Pada pembuatan yoghurt kontrol besarnya pembentukkan produk (Y p/s ) sebesar 0,082 mg, yoghurt putih $0,139 \mathrm{mg}$, yoghurt ungu 0,0712 $\mathrm{mg}$, dan yoghurt orange sebesar $0,1046 \mathrm{mg}$.

Bakteri Lactobacillus bulgaricus dan Streptococcus thermophilus merupakan bakteri pembentuk asam laktat yang berperan dalam 
produksi yoghurt. Oleh karena itu, selain tumbuh dan berkembang, kedua mikrobia tersebut juga melakukan aktivitasnya, yaitu merombak laktosa menjadi asam laktat dalam susu fermentasi melalui jalur glikolisis. Dengan adanya aktivitas bakteri asam laktat, maka laktosa yang ada dalam yoghurt akan mengalami penurunan dan terjadi kenaikan kadar asam laktat. Penambahan oligosakarida di dalamnya juga akan berpengaruh terhadap kandungan substrat dalam media. Substrat ini akan digunakan oleh sel untuk pertumbuhan dan pemeliharaan sel, dan juga digunakan untuk pembentukkan produk. Kenaikan asam laktat dalam fermentasi susu selalu seimbang dengan penurunan $\mathrm{pH}$ yoghurt, artinya semakin besar kadar asam laktat yang terbentuk selama fermentasi maka $\mathrm{pH}$ yoghurt semakin turun, tetapi penurunan kadar laktosanya tidak selalu seimbang dengan kenaikan kadar asam laktat.

Nilai $Y_{X / S}$ dan $Y_{p / s}$ dapat diartikan bahwa semakin tinggi nilai $\mathrm{Y}_{\mathrm{X} / \mathrm{s}}$ menunjukkan semakin banyak substrat yang digunakan untuk pertumbuhan sel dibanding pembentukan produk. Secara berurutan yoghurt putih sebagian besar substratnya dimanfaatkan untuk pembentukan produk daripada digunakan untuk pertumbuhan sel. Sedangkan yoghurt orange memanfaatkan substrat untuk pertumbuhan sel lebih banyak dibandingkan dengan yoghurt kontrol, tetapi yoghurt orange juga membantuk produk lebih tinggi dibandingkan dengan yoghurt kontrol, dan yoghurt ungu lebih memanfaatkan substratnya untuk membentuk dan memelihara sel daripada membentuk produk.

Pada yoghurt ungu dan orange substrat yang ada di dalam yoghurt dimanfaatkan oleh bakteri untuk pertumbuhan sel. Hal ini bisa dilihat pada data jumlah sel selama 15 jam fermentasi. Jumlah sel dari kedua yoghurt ini memilki jumlah sel yang lebih banyak dibandingkan dengan jumlah sel pada yoghurt kontrol dan yoghurt putih. Hal ini berarti penambahan ekstak ubi jalar berpengaruh terhadap pembentukkan produk selama fermentasi yoghurt.

\section{f. Efisiensi Pembentukan Asam Laktat Selama Fermentasi}

Efisiensi pembentukan asam laktat selama proses fermentasi yoghurt berkaitan dengan optimalisasi seberapa besar persentase substrat (laktosa) yang akan diubah menjadi produk (asam laktat). Pada kebanyakan proses fermentasi, efisiensi pembentukan produk diharapkan dengan adanya substrat yang ada dapat menghasilkan produk yang maksimal.
Dalam hal ini berkaitan dengan penambahan substrat berupa karbohidrat dari golongan oligosakarida dalam ubi jalar. Untuk fermentasi yoghurt pada pemanfaatannya pembuatan yoghurt dikehendaki kadar asam laktat tertentu.

Efisiensi dalam fermentasi yoghurt ini selain dioptimalkan pada perombakan laktosa menjadi asam laktat. Hal ini juga berkaitan dengan efisiensi waktu pemeraman yakni dengan penggunaan waktu pemeraman yang sama, jenis perlakuan yang mana yang paling tinggi nilai efisiensi pembentukan asam laktatnya. Berdasarkan nilai efisiensi pembentukan asam laktat dapat diketahui bahwa jenis perlakuan mana yang mempuyai aktivitas paling tinggi.

Penentuan efisiensi pembentukan asam laktat selama proses fermentasi yoghurt ini didasarkan pada kadar laktosa mula-mula dibagi dengan kadar asam laktat yang terbentuk sampai akhir proses fermentasi yang telah dihitung secara teoritis. Tabel 1 menunjukkan bahwa efisiensi pembentukan asam laktat pada fermentasi yoghurt kontrol adalah 7,374\%, yoghurt putih $6,458 \%$, yoghurt ungu $4,739 \%$, dan yoghurt orange $6,479 \%$. Hal ini berarti bahwa efisiensi kandungan laktosa yang ada dalam medium untuk yoghurt orange adalah sebesar $6,479 \%$ yang telah dirombak menjadi asam laktat, jadi tidak semua laktosa yang dirombak menjadi asam laktat.

Berdasarkan parameter nilai efisiensi pembentukan asam laktat ini dapat diketahui bahwa yoghurt kontrol mempunyai nilai efisiensi yang paling tinggi karena substrat dalam yoghurt dimanfaatkan secara optimal untuk pembuatan poduk. Yoghurt ungu mempunyai nilai efisiensi yang paling rendah, hal ini dimungkinkan karena pada yoghurt ungu, substratnya dimanfaatkan secara optimal dalam pembentukan sel sehingga pembentukan produk tidak dapat dicapai secara optimal. Hal ini dapat berarti bahwa penambahan ekstrak ubi jalar berpengaruh terhadap efisiensi pembentukan asam laktat.

\section{KESIMPULAN}

Kesimpulan dari penelitian ini menunjukkan bahwa kinetika fermentasi yoghurt yang diperkaya dengan ubi jalat adalah sebagai berikut :

a. Besarnya nilai kecepatan pertumbuhan spesifik $(\mu)$ pada yoghurt orange adalah $0,05880 / \mathrm{jam}$, yoghurt ungu 0,5589/jam, yoghurt kontrol 0,4809/jam, dan yoghurt putih $0,4510 / \mathrm{jam}$. Berdasarkan nilai parameter kecepatan pertumbuhan spesifik penambahan 
ekstrak ubi jalar orange adalah yang paling efektif.

b. Besarnya waktu penggandaan sel ( td ) pada yoghurt putih adalah 1,8393 jam yoghurt kontrol 1,4513 jam, yoghurt ungu 1,3806 jam dan yoghurt orange 1,2074 jam. Berdasarkan nilai parameter waktu penggandaan penambahan ubi jalar orange adalah yang paling efektif.

c. Besarnya derajat multiplikasi (n) pada pembuatan yoghurt yang diperkaya ubi jalar orange adalah 6,0985 kali, yoghurt ungu 5,6837 kali, yoghurt putih 5,5671, dan yoghurt kontrol 4,9567. Berdasarkan nilai parameter derajat multiplikasi penambahan ekstrak ubi jalar orange merupakan starter yang paling efektif.

d. Besarnya Hasil Pertumbuhan ( $\left.\mathrm{Y}_{\mathrm{X} / \mathrm{S}}\right)$ dan Pembentukan Produk $\left(\mathrm{Y}_{\mathrm{p} / \mathrm{s}}\right)$ berurutan pada pembuatan yoghurt putih adalah 4,2 $\mathrm{x} 10^{5} \mathrm{cfu} / \mathrm{mg}$ dan 0,139 , yoghurt orange adalah $6,8 \times 10^{5} \mathrm{cfu} / \mathrm{mg}$ dan 0,1046 ,yoghurt ungu adalah $7,5 \times 10^{5} \mathrm{cfu} / \mathrm{mg}$ dan 0,072 , dan yoghurt

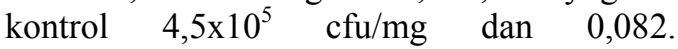
Berdasarkan nilai parameter hasil pertumbuhan dan pembentukan produk penambahan ekstak ubi jalar putih adalah yang paling efektif.

e. Besarnya efisiensi pembentukan asam laktat selama fermentasi yoghurt kontrol adalah $7,633 \%$, yoghurt orange $6,479 \%$, yoghurt putih 6,458\%, dan yoghurt ungu 4,739\%. Berdasarkan nilai parameter efisiensi pembentukan asam laktat pelakuan dengan tanpa penambahan ekstrak ubi jalar merupakan perlakuan yang paling efektif.

\section{SARAN}

1. Penambahan ekstrak ubi jalar ternyata dapat menjadi salah satu alternatif untuk memanfaatkan ubi jalar sebagai sumber prebiotik bagi probiotik. Sehingga perlu dilakukan penelitian lebih mendalam lagi guna pemanfaatan ubi jalar yang lebih optimal.

2. Pembuatan ubi jalar pada pembuatan yoghurt sebaiknya dilakukan sekitar 10 jam saja, karena pada interval itu menunjukkan jumlah bakteri yang tinggi.

\section{DAFTAR PUSTAKA}

Apraidji, Wied Harry. 2006. Khasiat ubi jalar. http://www.pitoyo.com/mod.php? (diakses 10 Desember 2008).

Choong C. Teow, Van-Den Truong, Roger F. McFeeters, Roger L. Thompson, Kenneth V. Pecota and, G. Craig Yencho. 2007. Antioxidant activities, phenolic and $b$ carotene contents of sweet potato genotypes with varying flesh colours. Food Chemistry 103 p. $829-838$

D. DEL POZO-INSFRAN, C. H. Brenes, S. T. Talcott, and H. Cantu. 2002. Determination of antimicrobial properties of anthocyanins naturally stabilized by flavonoids. Annual Meeting and Food Expo-Anaheim, California

Judoamidjojo, M., Abdul, A. D, dan Endang G. S., 1992. Teknologi Fermentasi. Rajawali Pers. Jakarta.

Sudarmadji, S., B. Haryono dan Suhardi. 1984. Prosedur Analisa untuk Bahan Makanan dan Pertanian. Liberty. Yogyakarta

Suwedo. 1994. Teori dan Prosedur Pengujian Mutu Susu dan Hasil Olahannya. PAU Pangan dan Gizi. Yogyakarta.

Widjanarko, Simon. 2008. Efek Pengolahan terhadap Komposisi Kimia \& Fisik Ubi Jalar Ungu dan Kuning. http://simonbwidjanarko.wordpress.com/ (diakses 3 Januari 2008).

\section{UCAPAN TERIMA KASIH}

Kami mengucapkan terima kasih kepada Dekan Fakultas Pertanian serta segenap pengurus KPPMF-FP UNS atas dana penelitian DIPA BLU Fakultas T.A. 2009. 